exists without comment on what might have been. Nevertheless, the historical view of vegetation is covered in a chapter by Sekina Ayyad, whose account of Egyptian palaeobotany and palynology underlines the immense opportunities that exist for further work in these two fields.

Any European botanist who has recently visited or worked in Egypt will have been impressed by the intensity of human impact on both the wetland and the arid vegetation. This book provides the basis for further studies on the processes involved in vegetation change and response to these human pressures and it also draws attention to the precarious position of certain vegetation types, such as those found in the saline depression of Wadi El Natrun - possibly the last site for Cyperus papyrus in the whole of Egypt. The site is heavily grazed and is subject to fluctuations in water level and salinity, and the effect of these variables on the survival of this and other scarce species, such as Typha elephantina, urgently needs to be studied.

Congratulations are due to Zahran and Willis on the production of a fine book. Let us trust that it results in the fourth and vital stage in biodiversity studies - the development of management techniques for the maintenance of the remaining fragments of this part of the world's plant resources.

Peter D. Moore is in the Division of Life Sciences, King's College, Campden Hill Road, London W8 7AH, UK.

\title{
Obsessive deconstruction
}

\section{William H. McNeill}

The Geographical Tradition. By David N. Livingstone. Blackwell: 1992. Pp. 434. £45, \$55 (hbk); £13.95, \$19.95 (pbk).

DAVID Livingstone's book is a fine example of intellectual history with a vengeance. His subject is geography as practised in the English-speaking world since about 1500 , with some side glances at Iberian forerunners and at German and French writers who impinged on the British and American geographical tradition. He brings substantial erudition and intensely self-conscious epistemological sophistication to bear on deconstructing the texts he examines. Yet, since the word 'truth' is absent from his vocabulary, what principally exercised the minds of the writers he discusses - the accuracy and adequacy of their ideas and data in relation to 'reality' — is absent from his account of their doings. Instead he looks for connections between their ideas and other facets of their lives. In his own words: "The heart of my argument is simply that geography changes as society changes, and that the best way to understand the tradition to which geographers belong is to get a handle on the different social and intellectual environments within which geography has been practiced."

Sometimes Livingstone's externalist approach successfully highlights unsuspected dimensions of dead geographers' mentalities. Thus he makes a good case for saying that Carl Sauer's regionalism was "as much as anything else, an exercise in moral recovery". Similarly, he asserts that pre-darwinian geography was divided between "outdoor practitioners and armchair philosophers. As to rhetoric, the former concentrated their endeavours on the inductive gathering of global data, though this was frequently an exercise in the fabrication of those facts best suited to the national interests of colonial power. By contrast, the theoreticians wanted to infuse such items of geographical particularity with a grander cosmic purpose and to identify in the agents of geographical change the hidden hand of divinity." These and many other judgements strike me as illuminating and convincing.

But all too often, Livingstone prefers denigration. For instance, he declares that the Eurocentric conceptualization of Captain Cook's reports from the south Pacific "became the tools of cultural subjection and the plundering of identity". What plundering an identity means is unclear to me, and I doubt whether Cook's conceptualizations of Polynesian behaviour had such a capability. Or to take a second example: Livingstone accuses Isaiah Bowman of "laying his geographical skills at the feet of the American Council on Foreign Relations and the State Department. Indeed, he himself emerged as an apologist of the American war effort in the 1940s." What does Livingstone think a university president ought to have done when Hitler and Tojo were on the offensive? Does a (very modest) political role vitiate Bowman's "uneasy claims to scientific objectivity" as Livingstone asserts? Or were his shortcomings rooted in epistemological naivety about scientific truth?

Livingstone's own epistemological sophistication does not present a very cheerful prospect. He affirms that "geographers will have to acknowledge that warranted knowledge is relative to a body of beliefs, not to a body of certitudes. Pluralism in the geographical academy is thus an inevitability. We have no option but to live with positivist geography, Marxist geography, humanistic geography, Islamic geography, structuralist geography, Christian geography, a people's geography and on and on. Each will be within their [sic] cognitive rights to hold to theories that comport with their system of control beliefs." [All are] "as legitimate now as they were in the fifteenth and sixteenth centuries, where my story began."

As Pilate said: "What is Truth?" Are any and all controlling beliefs really equal? Even if a logical demonstration of how words and things match up is impossible, is there no evolutionary strain towards accuracy and adequacy of conceptualization? Don't some ideas work better than others? Are there no restraints on the unbridled imagination?

In fact, Livingstone clearly does believe that the globe is spherical; that Columbus possessed "detailed knowledge of the wind circulation systems of the sea" and that maps have some sort of relation to what exists, since "the emerging map of the world must rank among the finest intellectual achievements of the age of discovery". His insistence that geographers of the fifteenth and sixteenth century were also affected by theology, magic and other contemporary ideas is also familiar. But when he turns to post-Enlightenment geography his deconstruction of old pieties becomes obsessive. He discerns motives (almost always unworthy) for new schools of thought, so that the history of geography becomes a tale of struggles for power among individuals, nations and academic disciplines. That such motives operated seems clear enough; and his account makes older visions of an ever-advancing science of geography look naive. But by dismissing the search for truth, disdaining the accumulation of information, and affirming that disgraceful motives were usually decisive, he looks in his own distorting mirror at the subtle, complex and confused Anglo-American geographical tradition.

William H. McNeill, emeritus professor of history at the University of Chicago, is at 36 Schoolhouse Road, PO Box 45, Colebrook, Connecticut 06021, USA.

Also just published is The Challenge for Geography edited by R. J. Johnston. Chapters cover the global economy (P. Dicken), social landscapes (S. J. Smith), geopolitics (G. Smith), human societies and environmental change (I. Simmons), land transformation (A. Goudie) and climate change (M. Parry). P. Taylor, P. Jackson and R. Abler examine the implications of these changes for the discipline of geography. Blackwell, $£ 50$ (hbk), £14.99 (pbk). 